\title{
Ueber die Aglykone des Sojasaponins. (I. Mitteil.)
}

$$
\text { von }
$$

\section{Munemaro MryasAKa}

[Aus dem Wissenschaftlichen Laboratorium der Firma Takeda-chôbei, Osaka)

(Eingegangen am 5. April 1937)

Y. Sumiki (J. Agricult. Chem. Soc. Japan, 5, 737 [1929]) hat das Sojasapogenin $\mathrm{C}_{32-35} \mathrm{H}_{48-56} \mathrm{O}_{3}$ vom Schmp. 228-241 ${ }^{\circ}$ durch Hydrolyse des Sojasapanins $\mathrm{C}_{49-52} \mathrm{H}_{70-84} \mathrm{O}_{21}$ vom Schmp. 222-224 ${ }^{\circ}$ gewonnen. Dann hat E. WALZ (A. 489, 118 [1931]) drei Sojasaponine (Saponin-C vom Schmp. 272 ${ }^{\circ}$, Saponin-C $C_{1}$ vom Schmp. $225^{\circ}$ und Saponin- $\mathrm{C}_{2}$ vom Schmp. 278-280 ${ }^{\circ}$ ) isoliert und durch Hydrolyse des Saponins-C und Saponins-C $\mathrm{C}_{1}$ zwei Sojasapogenine vom Schmp. 235-236 ${ }^{\circ}$ und Schmp. 243-245 ${ }^{\circ}$ erhalten. Bald darauf haben K. Okano und I. Ohara (J. Agricult. Chem. Soc. Japan, 9, 1249 [1933]) zwei Sojasapogenine vom Schmp. 128-249 ${ }^{\circ}$ und Schmp. 120-313 ${ }^{\circ}$ durch Hydrolyse von Sojasaponine $\mathrm{C}_{48-50} \mathrm{H}_{77-81} \mathrm{O}_{18}$ vom Schmp. 225-227 und $\mathrm{C}_{49-51} \mathrm{H}_{72-83} \mathrm{O}_{19}$ vom Schmp. $216-218^{\circ}$ gewonnen. K. Hattori, Ogimura und Okumura (J. Hygien. Chem. Soc. Japan, 5, 313 [1933]) haben zwei Sojasaponine (Saponin-I vom Schmp. $265^{\circ}$ und Saponin-II vom Schmp. 217-218 ${ }^{\circ}$ ) gefunden und durch Hydrolyse jedes Saponins zwei Sojasapogenine, $\mathrm{C}_{29} \mathrm{H}_{52} \mathrm{O}_{4}$ vom Schmp. $249^{\circ}$ und $\mathrm{C}_{26} \mathrm{H}_{42} \mathrm{O}_{3}$ vom Schmp. $241^{\circ}$, erhalten. R. C. Burell und E. D. Walter. (J. biol. Chem., 108, 55 [1935]) haben ein saures Sojasapogenin vom Schmp. 198$200^{\circ}$ aus dem Sojasaponin vom Schmp. 220-225 ${ }^{\circ}$ dargestellt.

Der Verfasser konnte nun zeigen, dass das Sojasaponin je nach der Art und Weise der Hydrolyse Sapogenine von verschiedenen Eigenschatten, die für sich als einheitlich erscheinen, liefert. Zum Beispiel bei 40 stündigem Erhitzen mit $5 \%$ iger alkoholischer Schwefelsäure erhielt er Genin-1 vom Schmp. $250^{\circ}$, bei 30 stündigem Erhitzen mit demselben Mittel Genin-II vom Schmp. $249^{\circ}$, während bei 25 stündigem Erhitzen mit $5 \%$ iger alkoholischer Salzsäure Genin-III vom Schmp. $238^{\circ}$, das bei weiterem 20 stündigem Erhitzen mit 15\% iger alkoholischer Schwefelsäure Genin-IV vom Schmp. $255^{\circ}$ liefert. 
Diese Genine sind Gemische von nah verwandten Verbindungen, deren Trennung bloss durch fraktionierte Krystallisation in keiner Weise gelingt. Erst durch Chromatographieren konnte der Verf. daraus drei scharf charakterisierte Sapogenole A, B und $\mathrm{C}$ isolieren. Lässt man nämlich die $0.1 \%$ ige Benzollösung der Roh-Genine durch eine lange Schicht vom aktiviertem Aluminiumoxyd durchstreichen und beobachtet das mit adsorbierten Substanzen beladene Aluminiumoxyd unter UltraviolettenStrahlen, so bemerkt man drei Hauptschichte : die oberste weisslich, die darauffolgende, ziemlich breite violett und die unterste, schmale hell violett erscheinend. Durch Extraktion mit Methanol erhält man aus der Obersten das Sojasapogenol-A, aus der mittleren das Sojasapogenol-B und aus der untersten das Sojasapogenol-C: (vergl. Tab. I).

\section{Tabelle I.}

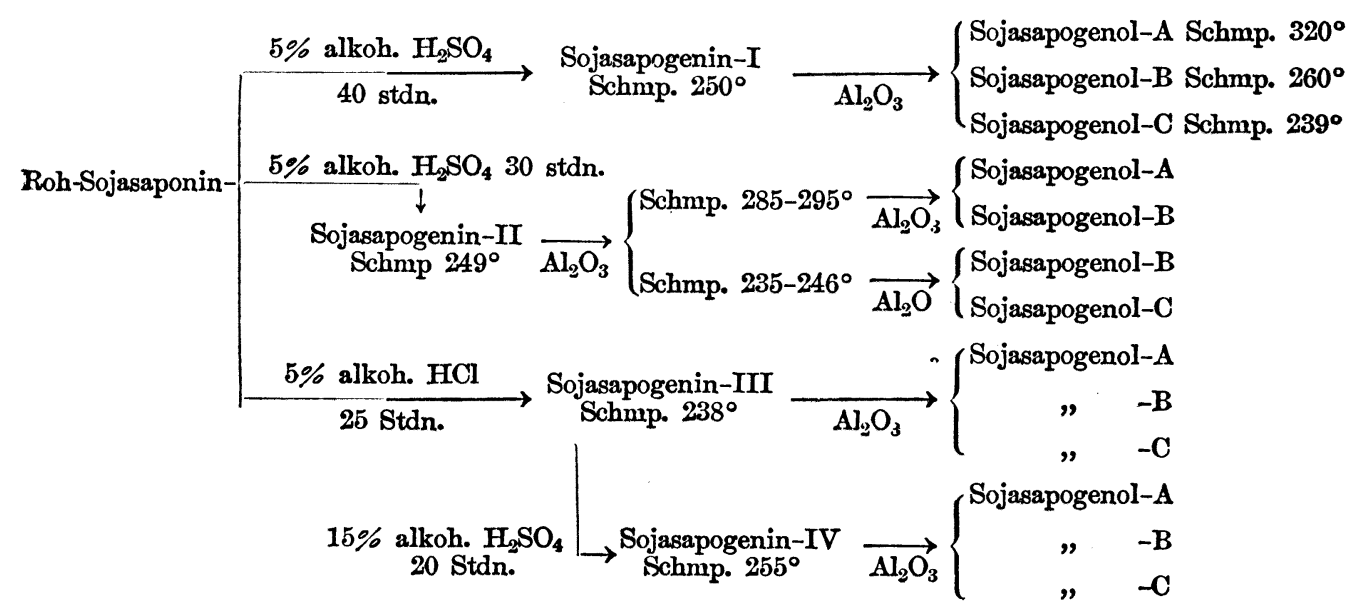

Diese Sojasapogenole zeigen blutrote Liebermannsche Reaktion, geben keine Digitonid-Fällungen mit Digitonin, reagieren neutral und besitzen keine Verseifungszahl. Sie sind löslich in Aether, Methanol, Alkohol, Chloroform und Aceton, schwer in Benzol und Petroläther. Die optische Eigenschaften der Krystalle von den Sojasapogenolen und deren Acetylverbindungen wurden unter den Poralisationsmikroskop untersucht (vergl. Tab. II). 
Tabelle II.

\begin{tabular}{|c|c|c|c|c|c|}
\hline & \multirow{2}{*}{ Krystallform } & \multicolumn{3}{|c|}{ Brechungsindices. Na-Licht } & \multirow{2}{*}{ Bemerkungen } \\
\hline & & $n \alpha$ & $\mathrm{n} \beta$ & ny & \\
\hline Sojasapogenol-A & Tafeln & $1.54_{7}$ & $1.56_{2}$ & . & $\begin{array}{l}\text { Doppelbrechung positiv. } \\
\text { Gerade Auslöschung }\end{array}$ \\
\hline Sojasapogenol-B & $\begin{array}{c}\text { Tafeln (Spezielle } \\
\text { Spaltbarkeit wird } \\
\text { beobachtet. }\end{array}$ & 1.540 & $1.54_{7}$ & 1.57 & Gerade Auslöschung \\
\hline Sojasapogenol-C & Tafeln & $1.53_{7}$ & $1.54_{7}$ & $1.57_{5}$ & Wie oben \\
\hline $\begin{array}{l}\text { Tetraacetyl-Sojasapo- } \\
\text { genol-A }\end{array}$ & Nadeln & $1.50_{7}$ & $1.51_{5}$ & $1.55_{0}$ & wie oben \\
\hline $\begin{array}{l}\text { Triacetyl-Sojasapoge- } \\
\text { nol-B }\end{array}$ & Tafeln & 1.527 & $1.53_{1}$ & 1.58 & wie oben \\
\hline
\end{tabular}

Sojasapogenol-A.

Sechseckige Krystalle aus Methanol. Schmp. $321^{\circ}$ (korr.). Drehungsvermögen in Alkohol : $[\alpha]_{\mathrm{D}}^{22}:+105.7^{\circ}$.

$$
\begin{array}{rrrrr}
\mathrm{C}_{29} \mathrm{H}_{48} \mathrm{O}_{4} \text { * } & \text { Ber. } & \text { C } 75.57 & \text { H } 10.51 & \text { M. G. } 460.4 . \\
& \text { Gef. } & \text { C } 75.59 & \text { H } 10.58 & \text { M. G. } 450.0 .
\end{array}
$$

Tetraacetat: Weisse Nadeln aus Methanol und Aceton. Schmp. 232 ${ }^{\circ}$ (korr.). Drehungsvermögen in Chloroform : $[\alpha]_{\mathrm{D}}^{15}:+86.1^{\circ}$.

$$
\begin{array}{rrrrr}
\mathrm{C}_{37} \mathrm{H}_{56} \mathrm{O}_{8} & \text { Ber. } & \text { C } 70.65 & \text { H } 8.98 & \text { M. G. 628.5. } \\
& \text { Gef. } & \text { C } 70.64 & \text { H } 8.72 & \text { M. G. 635.1. }
\end{array}
$$

Tribenzoat: Schuppen aus Methanol und Aceton. Schmp. 255 (korr.).

$$
\begin{array}{rllll}
\mathrm{C}_{29} \mathrm{H}_{45} \mathrm{O}\left(\mathrm{O} \cdot \mathrm{COC}_{6} \mathrm{H}_{5}\right)_{3} & \text { Ber. } & \text { C } 77.67 & \text { H } 7.83 & \text { M. G. } 772.5 . \\
& \text { Gef. } & \text { C } 77.36 & \text { H } 7.92 & \text { M. G. } 765.8 .
\end{array}
$$

Sojasapogenol-B.

Rechteckige Krystalle aus Methanol oder Aceton. Schmp. $260^{\circ}$ (korr.).

$$
\begin{array}{rrrrr}
\mathrm{C}_{27} \mathrm{H}_{44} \mathrm{O}_{3} & \text { Ber. } & \text { C } 77.88 & \text { H } 10.65 & \text { M. G. 416.4. } \\
& \text { Gef. } & \text { C } 78.19 & \text { H } 10.65 & \text { M. G. 422.3. }
\end{array}
$$

Drehungsvermögen : $[\alpha]_{\mathrm{D}}^{15}:+91.23$ in Chloroform.

Triacetat: Rechteckige Tafeln aus Methanol. Schmp. $180^{\circ}$ (korr.).

$$
\begin{array}{rrrrr}
\mathrm{C}_{27} \mathrm{H}_{41}\left(\mathrm{O} \cdot \mathrm{COCH}_{3}\right)_{3} & \text { Ber. } & \text { C } 73.01 & \text { H. 9.29 } & \text { M. G. 542.4. } \\
& \text { Gef. } & \text { C } 73.29 & \text { H. 9.05 } & \text { M. G. 545.7. }
\end{array}
$$


Drehungsvermögen $[\alpha]_{D}^{16}:+82.96$ in Chloroform.

Tribenzoat: Nädelchen aus Methanol und Aceton. Schmp. $183^{\circ}$ (korr.).

$\mathrm{C}_{27} \mathrm{H}_{41}\left(\mathrm{O} \cdot \mathrm{COC}_{6} \mathrm{H}_{5}\right)_{3} \quad$ Ber. $\quad$ C 79.08 H 7.75 M. G. 728.45.

$\begin{array}{llll}\text { Gef. } & \text { C } 79.34 & \text { H } 7.74 & \text { M. G. } 720.1 \text {. }\end{array}$

Sojasapogenol-C.

Rechteckige Tafeln aus Methanol. Schmp. 239 ${ }^{\circ}$ (korr.).

$\mathrm{C}_{23} \mathrm{H}_{36} \mathrm{O}_{2}$ Ber. C 80.16 H 10.54 M. G. 344.29.

Gef. $\quad$ C 79.88 H 10.73 M.G. 330.2.

(Autoref.) 


\title{
大豆サポニンのアグリコンに就いて（第一報）
}

\author{
宮 坂 宗 魔
}

\section{(株式會社武田長兵衞商店研究部)}

(昭和 12 年 4 月 5 日受理)

M. Miyasaka : Über die Aglykone des Snjasaponins.

1929 年任木諭介氏1) は Zp. 222-40 の酸性大豆サポ=ン $\left.\mathrm{C}_{49-52} \mathrm{H}_{70-84} \mathrm{O}_{-11}\right)$ を加水分解し，其

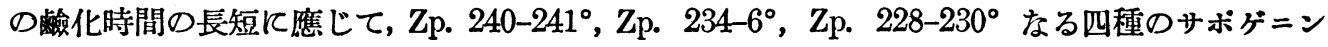
を得，各その $\mathrm{C}, \mathrm{H}$ ，站びに分子量測定の結果を綜合して， $\mathrm{C}_{32-35} \mathrm{H}_{48-56} \mathrm{O}_{3}$ なる分子式を與へた.

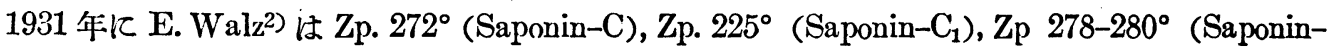
$\mathrm{C}_{2}$ ) なる三種の大豆サポニンを分離し，Saponin-C ょり Fp. 235-236，一C より Fp. 243$245^{\circ}$ のサポゲニンを分離した. 又 1933 年に岡野, 小原兩氏 3$)$ は $\mathrm{Zp.} 225-227^{\circ}\left(\mathrm{C}_{48-50} \mathrm{H}_{77-81} \mathrm{O}_{18}\right)$ Zp. 216-218 $\left(\mathrm{C}_{49-61} \mathrm{H}_{79-83} \mathrm{O}_{19}\right)$ なる二種の大豆サポニンを鹼化し，其の畧化時間の長短，立び 飞 $\mathrm{CCl}_{4}$, Ligroin 等飞對する溶解度の差を利用して, 前者より Zp. $128^{\circ}, 235^{\circ}, 239^{\circ}, 260^{\circ}, 248$ $249^{\circ}$ ，なる五種のサポゲニンを得，其の各くの分析端びに分子量測定の結果を綜合して分子式 を $\mathrm{C}_{30-32} \mathrm{H}_{48-52} \mathrm{O}_{3}$ と定め, 後者より同梯にして, $\mathrm{Zp} .120^{\circ}, 224-226^{\circ}, 293-294^{\circ}, 313^{\circ}$ なる五 種のサポゲニンを得，分子式を $\mathrm{C}_{31-33} \mathrm{H}_{50-54} \mathrm{O}_{4}$ と定めた。 1933 年服部，荻村，奥村氏4) は $\mathrm{Fp}$. $265^{\circ}$ (Saponin-I), Fp. 217-218 (Saponin-II) なる二種の大豆サポニンを分離し, Saponin-II を加水分解して Fp. $249^{\circ}$ のサボゲニンを得, 分子式 $\mathrm{C}_{29-30} \mathrm{H}_{50-54} \mathrm{O}_{4}$ を與へた. 其後荻村氏5) は Saponin-I を加水分解し, Fp. 241 Kは R. C. Burell, E. D. Walter6) は Zp. 220-2250 のサポニンょり Zp. 198-200。を示す酸 性サポゲニンを得をと報告して居る。

以上在來の文獻にある大豆サポニンのアグリコンと著者の得をるアグリコンとを一括表示す れば第一表の通りである。

(第 表)

\begin{tabular}{|c|c|c|}
\hline & Sojasaponin (Fp. od Zp.) & Sojasapogenin (Fp.) \\
\hline 佳木') & $\mathrm{C}_{29-52} \mathrm{H}_{70-84} \mathrm{O}_{21}\left(\mathrm{Z}\right.$ p. $\left.222-4^{\circ}\right)$ & $\mathrm{C}_{32-35} \mathrm{H}_{48-56} \mathrm{O}_{3}\left(\right.$ Fp. $\left.228-241^{\circ}\right)$ \\
\hline \multirow{3}{*}{ E. Walz.2) } & C-Saponin. (Zp. 272 $\left.{ }^{\circ}\right)$ & Fp. $235-236^{\circ}$ \\
\hline & $\mathrm{C}_{1}$-Saponin. (Fp. $225^{\circ}$ ) & Fp. $243-245^{\circ}$ \\
\hline & $\mathrm{C}_{2}$-Saponin. (Fp. 278-280 $)$ & \\
\hline
\end{tabular}




\begin{tabular}{|c|c|c|}
\hline & Sojasaponin (Fp. od $Z_{p}$.) & Sojasapogenin (Fp.) \\
\hline \multirow{2}{*}{ 网野,小原3) } & $\mathrm{C}_{48-50} \mathrm{H}_{7 z-81} \mathrm{O}_{18}\left(\right.$ Fp. $\left.22 \overline{0}-7^{\circ}\right)$ & $\mathrm{C}_{30-32} \mathrm{H}_{48-52} \mathrm{O}_{3}($ Fp. 128-249 $)$ \\
\hline & $\mathrm{C}_{47-51} \mathrm{H}_{79-8,} \mathrm{O}_{19}\left(\right.$ Fp. $\left.216-218^{\circ}\right)$ & $\mathrm{C}_{31-32} \mathrm{H}_{50-54} \mathrm{O}_{4}\left(\right.$ Fp. $\left.120-313^{\circ}\right)$ \\
\hline 眼部，获村，奥村4) & $\mathrm{C}_{52} \mathrm{H}_{88-90} \mathrm{O}_{23}\left(\mathrm{Zp.} 217^{\circ}\right)$ & $\mathrm{C}_{29} \mathrm{H}_{52-54} \mathrm{O}_{4}\left(\right.$ Fp. $\left.249^{\circ}\right)$ \\
\hline 获村5) & $\mathrm{C}_{52-5.3} \mathrm{H}_{86-92} \mathrm{O}_{23}\left(\right.$ Fp. $\left.265^{\circ}\right)$ & $\mathrm{C}_{26} \mathrm{H}_{42} \mathrm{O}_{3}\left(\right.$ Fp. $\left.240-241^{\circ}\right)$ \\
\hline R. C. Burell, E. D. Walter.6) & Fp. $220-225^{\circ}$ & Fp. $198-200^{\circ}$ \\
\hline \multirow{3}{*}{ 宮坂 } & \multirow{3}{*}{ Roh-Saponin. } & $\mathrm{C}_{29} \mathrm{H}_{48} \mathrm{O}_{4}$ (Fp. 321. . (korr.)) \\
\hline & & $\mathrm{C}_{27} \mathrm{H}_{44} \mathrm{O}_{3}$ (Fp. $260^{\circ}$. (korr.)) \\
\hline & & $\mathrm{C}_{23} \mathrm{H}_{36} \mathrm{O}_{2}$ (Fp. $239^{\circ}$. (korr.)) \\
\hline
\end{tabular}

双, 以上の䝷驗例に依て見ても解るやらに, 大豆サポニンには數種あるものの如く, 從て加水 分解に依て生ずるアグリコンに異つたものが幾つか存在するであらうととも考人得られる。 こで著者は總サボゲニンを研究する目的で，大豆のアルコールェキスを Benzol を游ひて極力 瞈脂し乾燥した粗製の總サボニンを Alkohol 中鑛酸を䏳ひて鹼化し，其の鹼化時間の長短に應 ビて, Fp. $250^{\circ}$ (Sojısapogenin-I), Fp. $249^{\circ}$ (Sojasapogenin-II), Fp. $238^{\circ}$ (ShjasapogeninIII)，等の Sojısapogenin を得た. 此等の各くを精製 Benzol そ溶解し，約 $0.1 \%$ の溶液とな し，之を M.rk 製 $\mathrm{Al}_{2} \mathrm{O}_{3}$ 塔中を通過させて, Chromatographische Adsorbtionsanalyse を行つ

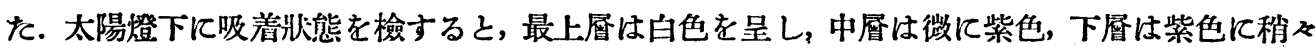
白色を帶びて居る. (第一圖參照). 各曆を Methanol で溫浸し，その蒸溜殘渣を更に Methanol から反覆再結晶すれば，上㒶吸着 部加 Fp. $321^{\circ}$ (korr.), Fp. $307^{\circ}$ (unkorr.), (Sojısapogeuol-A), 中 厤加 5 F. $260^{\circ}$ (korr.), Fp. $251^{\circ}$ (unkorr.), (Soj ısapogenol-B), 下 屏加 Fp. $239^{\circ}$ (korr.), Fp. $231^{\circ}$ (unkorr.), (Sojasapogenol-C) の Sojasapogenol (著者の得た Aglykon は中性であるから-Genol と

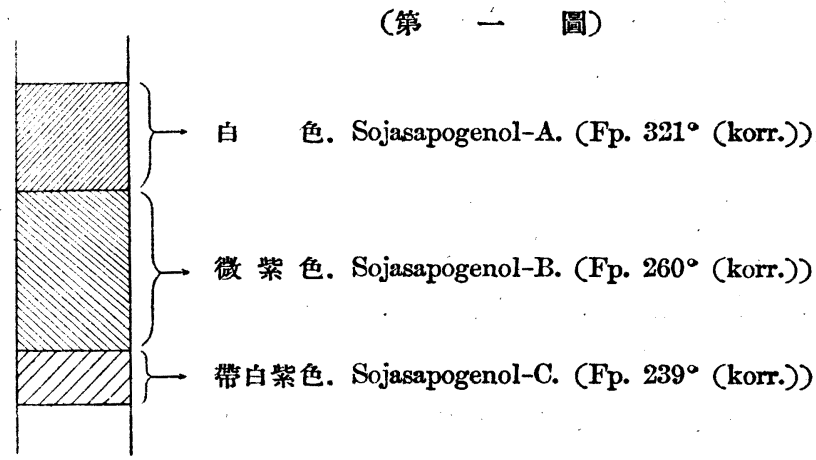
云ふ Suffx を用ひるとととした）が得られる. 份 Sojasaponin-III を 15\%の Alkohol 硫 酸にて 20 時間者沸して得た Fp. $255^{\circ} の$ Sojasapogenin-IV を同栐に $\mathrm{Al}_{2} \mathrm{O}_{3}$ 塔を通過させ Sojasapogenol-A, -B, -C の三種に分離し得た. 收得量は粗製の Sojasapogenin-I $3 \mathrm{~g}$ 加 Roh-Sojasapogenol-A $1.2 \mathrm{~g}$, Roh-Sojasapogenol-B $1.5 \mathrm{~g}$, Roh-Sojasapogenol-C $0.3 \mathrm{~g}$ の程度が 
普通であつた.（第二表參照）.

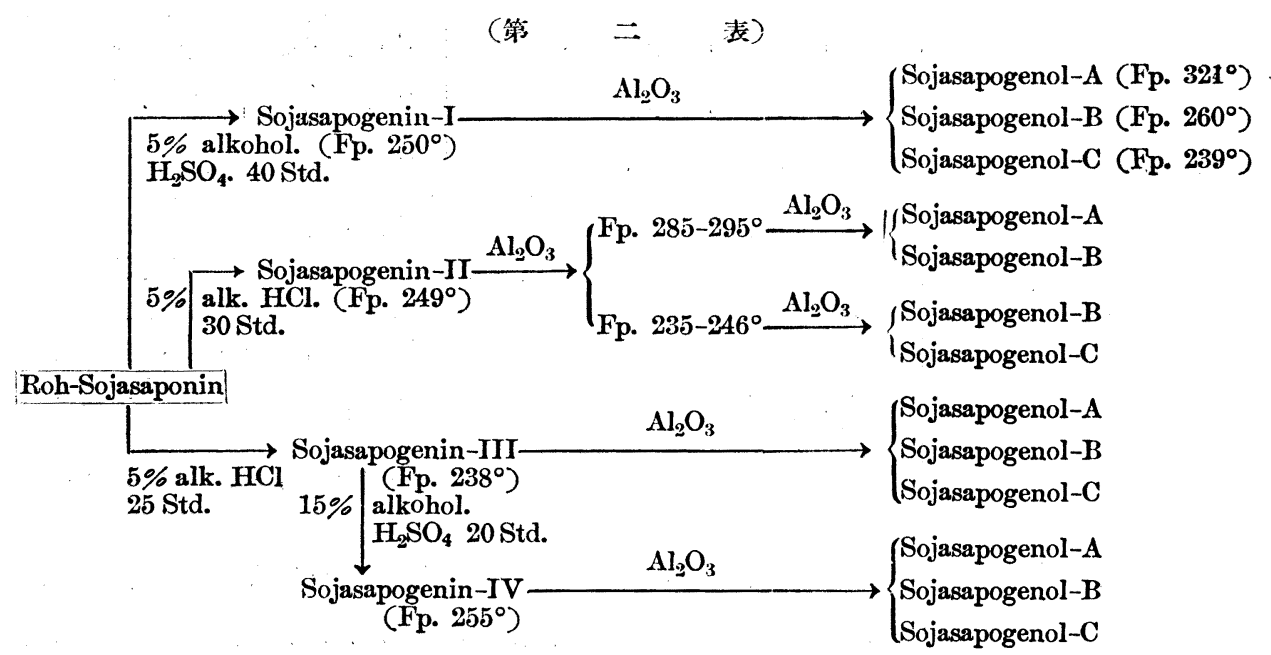

份, Sojasapogenol-A, -B, -C, 及び其の. Acetat の光學的性質を偏光顯微鏡下に比較すれば 第三表の如くなる. (寫訔參照).

Sojasapogenol-A \& Methanol, Alkohol 飞熱時易溶, Aether 飞易溶, Chloroform, Benzol に稍ぬ難溶, Liebermann の Phytosterin 反應は鮮紅色より紫赤色に至り, 16 時間後櫻實紅色 に變り永く此の色に留る. Salkowski-Hager 反應は Chlorform 層無色，硫酸層は黃色より約 20 分後に橙赤色を經て血赤色になる。箼硫酸上に散布すれば黃色より橙黃色を經て橙赤色に至 る: Tetranitromethan の Chloroform 溶液に依り黄色を呈すし, Digitonin に依て Digitonid を生成しない. Methanol より數回再結晶を反覆し, 份 Acetonより再結晶すれば無色長大六角 板狀の結晶となり，稍く吸濕性を帶び，Fp. 321 (korr.) を示す. Alkohol 溶液として旋光度 を測定すれば $[a]_{\mathrm{D}}^{22}=+105.7^{\circ}$. 紫外部にも特異な吸收スペクトルを現さない. Hanus 法に依り 二重結合數を测定すれば $F_{2}$ を得るが，本品を Alkohol 溶液とし，又は水醋酸に溶解し，Adams の酸化白金を觸媒として，水素䱊流中長特間振盪したが水素の吸收は 認められぬ. 從つて活性 二重結合の存在は考へられない. 又, 中性溶液に於ては過マンガン酸加里の脫色も起らなかつ た. 本品の Alkohol 溶液に 5\%の加里卤液を加へて, 一時間水浴上に者沸しても Alkali の消 費はない. 故に Lacton'又は Ester の存在は考へられぬ。本品は Oxim 又は Semicarbazon 专 生成しない. $20 \mathrm{~mm}$ の減壓下 $140-150^{\circ}$ にて 5 時間又は $110-120^{\circ}$ にて 8 時間乾燥後分析 を施行すれば, $\mathrm{C} \%=75.59, \mathrm{H} \%=10.58$ を示し, 又 Rast 法に低り分子量を測定すれば, M.G.= 450 附近の値を得る. 分子式を $\mathrm{C}_{29} \mathrm{H}_{48} \mathrm{O}_{4}$ とすれば, $\mathrm{C} \%=75.59, \mathrm{H} \% 10.51$, M.G. $=460.4$ とな り極めて良く一致する。

無水醋酸と無水醋酸ソーダとにより常法の如くアセチル化體を作れば, Tetracetat を生じ, 


\section{(顯 微 鏡 竄 異) “}

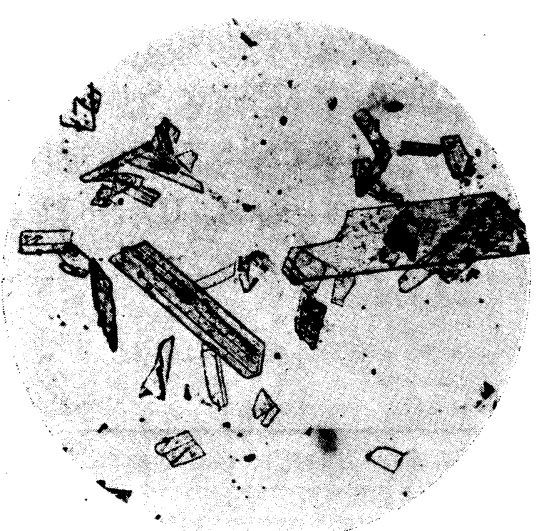

- Sojasapogenol-A $(\times 40)$

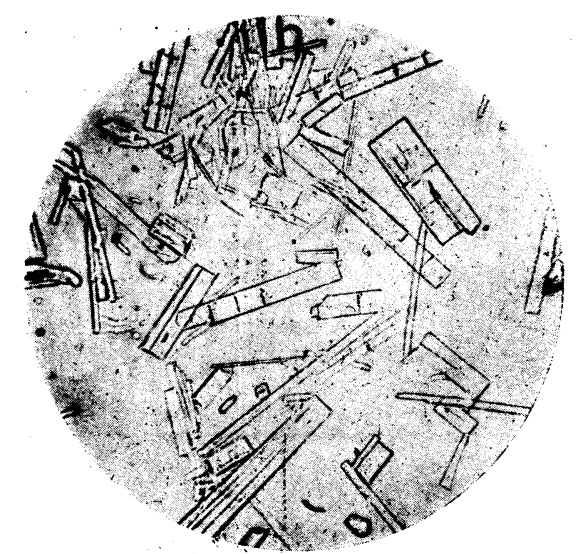

Sojasapogenol-B $(\times 130)$

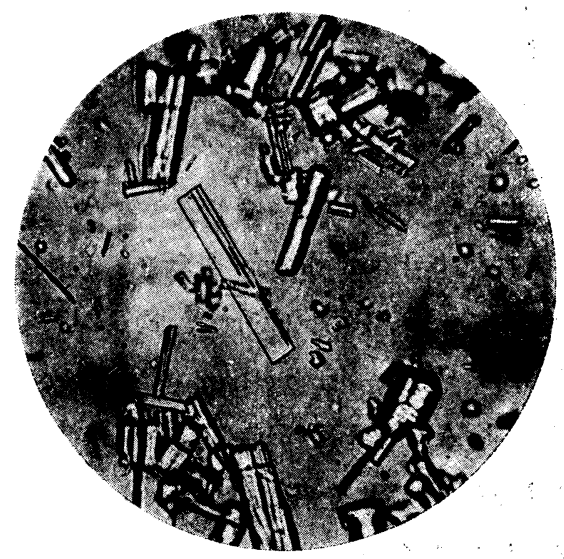

Sojasapogenol-C $(\times 250)$

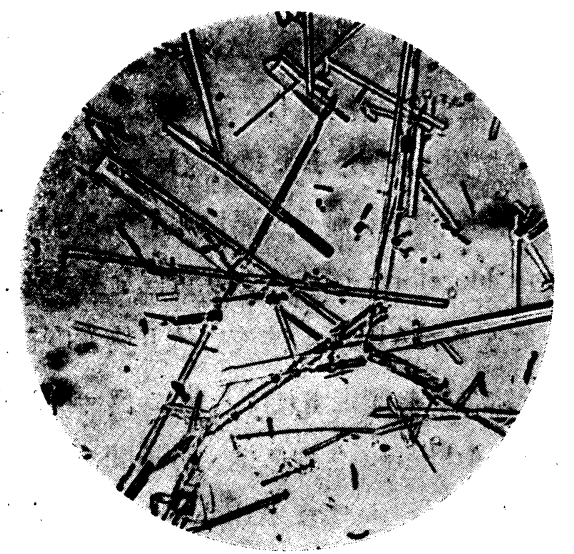

Tetracetyl-sapogenol-A $(\times 140)$

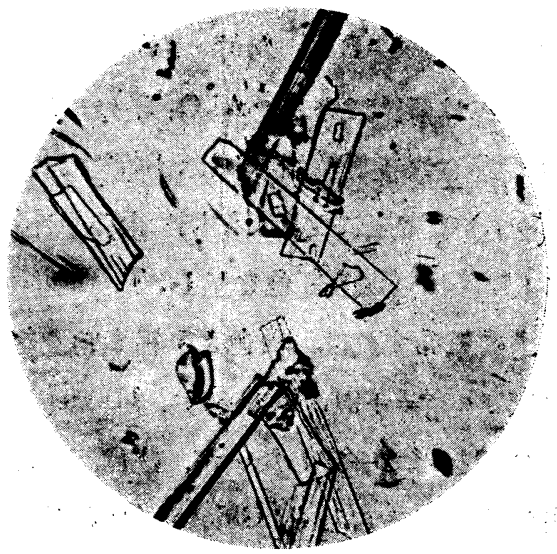

Triacetyl-sapogenool-B $(\times 140)$ 
Methanol より反覆再結晶すれば，Fp. 232 (korr.)，Fp. 225 (unkorr.) に固定する.ての Acetat の Liebermann 反應は鮮紅色を呈し，永く此の色調を保ち, Tetranitromethan の Chloroform 溶液を加一ると鮮明な黃色を呈する。一般有機溶媒に對する溶解度は Sojasapogenol一A 自身よりも增大し，吸濕性は無くなる．Chloform 溶液に於ける旋光度は $[a]_{\mathfrak{w}}^{15}=+86.1^{\circ}$. 約 $20 \mathrm{~mm}$ の減涯下にて $150^{\circ} ， 8$ 時間乾燥後分析を施行すれば， $\mathrm{C} \%=70.64 ， \mathrm{H} \%=8.72$ を得, Rast 法に依る分子量は M.G.=635.1. $\mathrm{C}_{29} \mathrm{H}_{44}\left(\mathrm{O} \cdot \mathrm{COCH}_{3}\right)_{4}$ とすれば， $\mathrm{C} \%=70.65, \mathrm{H} \%=8.98$, M.G. $=628.5$ となる. 光學的性質は第三表參照.

\begin{tabular}{|c|c|c|c|c|c|}
\hline \multirow[t]{2}{*}{ v } & \multirow{2}{*}{ 䊅＼cjkstart晶 形 } & \multicolumn{3}{|c|}{ 屈 折 來 (Na-光) } & \\
\hline & & $n_{l}$ & $\mathbf{n}_{\beta}$ & n & \\
\hline Sojasapogenol-A & 六角形の板狀 & $1.54_{7}$ & $1.56_{2}$ & - & $\begin{array}{l}\text { 直消光. } \\
\text { 重屈折正: }\end{array}$ \\
\hline Sojasapogenol-B & $\begin{array}{l}\text { 長方板狀. 特異 } \\
\text { なる辟開性あ. }\end{array}$ & $1.54_{0}$ & $1.54_{7}$ & $1.57_{5}$ & 直消光 \\
\hline Sojasapogenol-C & 長方板狀 & $1.53_{7}$ & $1.54_{7}$ & $1.57_{5}$ & 直消光 \\
\hline Tetracetyl-Sapogenol-A & 針狀 & $1.50_{7}$ & $1.51_{5}$ & 1.55 & 直消光 \\
\hline Triacetyl-Sapogenol-B & 板狀 & $1.52_{\tau}$ & $1.53_{1}$ & 1.58 & $\begin{array}{l}\text { 直消光 } \\
\text { 重届折正 }\end{array}$ \\
\hline
\end{tabular}

Pyridin 中 Benzoylchlorid に依り Benzoylieren を行ひ, 反應生成物を Aceton と Methanol

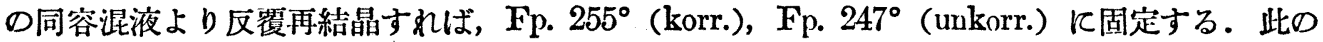
ものの Lieberman 反應は鮮紅色, Tetranitromethan の Chloroform 溶液により黄色を呈し, Aceton, Ather に易溶, Methanol, Alkohol 飞難溶である. C, H, 分析站びに分子量測定の結果 は, $\mathrm{C} \%=77.36, \mathrm{H} \%=7.92$, M.G.=765.8 を得, Tribenzoat $\mathrm{C}_{29} \mathrm{H}_{45} \mathrm{O}\left(\mathrm{O} \mathrm{COC}_{6} \mathrm{H}_{5}\right)_{3}$ として $\mathrm{C} \%=$ 77.67, H\%=7.83, M.G.=772.5 に上く一致する. 郎ち 1 個の $\mathrm{OH}$ は第三級の $\mathrm{OH}$ と考へら れる.

Sojasapogenol-B は Aether, Chloroform 飞易溶, Methanol, Alkohol, Aceton 飞稍飞難溶, Benzol Kは難溶である. $\mathrm{Al}_{2} \mathrm{O}_{3}$ 塔の中層から Methanol を䏳ひて浸出し，その蒸溜殘渣を Methanol から反覆再結晶すれば, $247^{\circ}$ で收縮し, $249^{\circ}$ で熔融し始め, Fp. $260^{\circ}$ (korr.), Fp. $251^{\circ}$ (unkorr.) で完全に熔融し澄明になる. 本品は無色板狀の結晶で, 幾分吸濕性を有する. Liebermaun 反應は鮮朋な紅色を呈し，TetranitromethanのChloroform 溶液により黄色を呈する．濃 硫酸上に散布すれば，黃色より橙黄色を經て橙赤色に至る. Alkohol 溶液に依り旋光度を測定 すれば $[a .]_{\mathrm{D}}^{5}=+91.23^{\circ}$ を示す. Hanus 法に化り二重結合数を测定すれば, 常に $F=3$ と 4 と の間の值を得て一定しないが，之は二重結合に BrJ が Addieren される他，分子間のどてかで 置換反應が起るらしく, Chloroform 層は常に黄褐色を呈する. 本品の Alkohol 溶液を Adams の酸化白金を觸媒として水素氣流中長時間振盪しても毫も水素の吸收は認められない. 又中性 
溶液に於て過マンガン酸加里の脫色も起ら奴. 本品を Alkohol 溶液中 5\%の Natronlauge を 加へて 1 時間煮沸しても Alkali は消費されない. 即ち Ester 叉は Lacton は存在しない. Oxim 又は Semicarbazon は生成されない. 約 $20 \mathrm{~mm}$ の減壓で 150-160, 8. 時間乾燥後分标 を施行すれば, C\%=78.19, H\%=10.65を得, Rast 法に依り分子量を測定すれば, M.G.=422.3 を得る。 $\mathrm{C}_{27} \mathrm{H}_{44} \mathrm{O}_{3}$ とすれば, $\mathrm{C} \%=77.88, \mathrm{H} \%=10.65, \mathrm{M} . \mathrm{G} .=416.4$ となり良く一致する.

無水醋酸と然水醋酸ソーダに依り常法の如くアセチル化體を作れば, Triacetat を生じ, Methanol より再結晶を反覆すれば，無色長大針狀結晶となり，熔融點は $180^{\circ}$ (korr.), $175^{\circ}$ (unkorr.) に固定する. Lieberman 反應は鮮紅色を呈し, Tetranitromethan の Chloroform 溶液に より鮮明な带色を呈する. Chloroform 溶液にて旋光度を測定すれば $[a]_{\mathrm{D}}^{16}=+82.96^{\circ}$ を得る. 一般有機溶媒に易溶で，吸濕性はない．本品の偏光顯微鏡下に見た光學的性質は第三表に示し た通りである.減壓約 $20 \mathrm{~mm}, 140-150^{\circ}$ にて 5 時間乾燥後分析を施行すれば, $\mathrm{C} \%=73.26$, $\mathrm{H} \%=9.05$, Rast 法に依り分子量を测定すれば，M.G.=545.7 を示す. $\mathrm{C}_{27} \mathrm{H}_{41}\left(\mathrm{O} \mathrm{COCH}_{3}\right)_{3}$ ～と すれば $\mathrm{C} \%=73.01, \mathrm{H} \%=9.29, \mathrm{M} . \mathrm{G} .=542.4$ となり良く一致する.

本品を Pyridin 中 Benzoylchlorid により常法の如く Benzoyl 化し, Benzoat を Aceton と Methanol の同容混液から反覆再結晶すれば，無色短針狀の結晶となり，Fp. 183 (korr.), Fp. $179^{\circ}$ (unkorr.) K固定する. 此のものの Liebermann 反應は鮮紅色, Tetranitromethan の Chloroform 溶液により黄色を呈し, Aceton, Aether, に易溶, Methanol, Alkohol に難溶であ る. C, H 分析站びに分子量测定の結果は, $\mathrm{C} \%=79.34, \mathrm{H} \%=7.74, \mathrm{M} . \mathrm{G} .=720.1$ を得, $\mathrm{C}_{27} \mathrm{H}_{41}$ $\left(\mathrm{O} \cdot \mathrm{COC}_{6} \mathrm{H}_{5}\right)_{3}$ とすれば, $\mathrm{C} \%=79.08, \mathrm{H} \%=7.75, \mathrm{M} . \mathrm{G} .=728.45$. となり良く一致する.

$\mathrm{Al}_{2} \mathrm{O}_{3}$ 塔中の下管を Methanol を椸ひて溫浸し，その蒸溜殘渣を Methanol から反覆再結晶 すれば, Fp. $239^{\circ}$ (korr.), Fp. 231 (unkorr.) の Sojasapogenol-C が得られる. 無色板狀の 結晶で幾分吸濕性を帶びて居る. Liebermann 反應は鮮渓色を呈し, Tetranitromethan の Chlo roform 溶液により㸖色を呈する. 有機溶媒に對する諸性質は Sojasapogenol-A, -B と同梯であ.

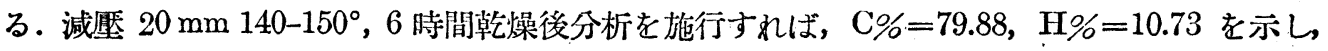
Rast 法による分子量は M.G.=330.2. $\mathrm{C}_{23} \mathrm{H}_{36} \mathrm{O}_{2}$ とすれば， C \%=80.16，H\%=10.54，M.G.= 344.3 となる. Sojasapogenol-C は未だ種々の誘導體を作つて登明するに至らないが，Chromatographische Adsorbtionsanalyse に於ける $\mathrm{OH}$ 基の數の小いもの程下層に吸着されると言ふ一 般法則と, Oxim の生成されない點, 又 Alkohol 溶液中 Alkalilauge と者沸するも Alkali の 消費されない點等から見て，2 個の酸素は $\mathrm{OH}$ 基の酸素と推定される.かくの如く $\mathrm{Al}_{2} \mathrm{O}_{3}$ 菭， の上首加ら分難した Sojasapogenol-A は，OH 4 基個を有し，中層から分離した Sojasapogenol$\mathrm{B}$ は $\mathrm{OH}$ 基 3 個を, 下層から取り出した Sojasapogenol-C は $\mathrm{OH}$ 基 2 個を有する事は著者 の興味を唆る事至大なものがある. 今, Sojasapogenol-A 竝びに Sojasapogenol-B と稍飞其の 
組成を同じくすると思はれる，敢部，荻村，奥村氏4)，5）等の得をる中性 Sojasapogenin とを比 較すれば第四表，第五表の如くなる，此の表て依て見れば著者の得たる Sojasapogenol-A，一B は般部，荻村，奥村氏等の得たる Sojasapogenin と略々同一物質と推定される。

(第 四表)

\begin{tabular}{|c|c|c|c|c|c|}
\hline 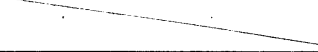 & 分子式 & 結晶形 & $F_{p}$ & Acetat (Fp.) & Oxim \\
\hline $\begin{array}{l}\text { 服部, 荻村, } \\
\text { 奥村 Sojasapogenin }\end{array}$ & $\mathrm{C}_{29} \mathrm{H}_{52-54} \mathrm{O}_{4}$ & 顆 粒 狀 & $249^{\circ}$ & Triacetat $\left(213^{\circ}\right)$ & Monoxim \\
\hline 宮坂 Sojasapogenol-A & $\mathrm{C}_{99} \mathrm{H}_{48} \mathrm{O}_{4}$ & 六解板狀 & $321^{\circ}$ & Tetracetat $\left(232^{\circ}\right)$ & 生成せず \\
\hline
\end{tabular}

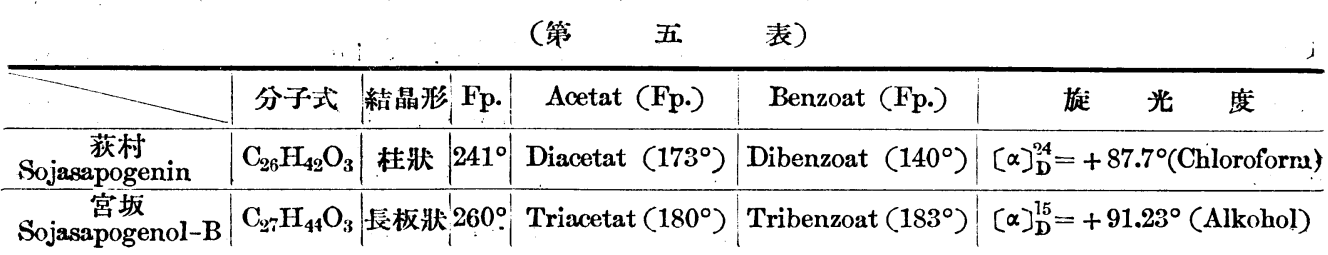

双て, Saponin 站びに Sapogenin 類に於ては其の精製の極めて困難なものが多く，從て其 の構造研究には先づ Saponin 又は Genin を純粹に取り出す事が先決問題である。

著者は最初 Methanol, Aceton 等を括ひて, Sojasapogenin-I, -II, -III, -IV 等より Sojasapogenol-A, - B , -C を分離し㥞と再三試みたが逐に成功するに至らなかつた. 之はSojasapogenol$\mathrm{A},-\mathrm{B},-\mathrm{C}$ の三者が極めて近似した構造と諸性質とを有し，從て有機溶媒を朎ひて三者を分割 する事は殆んど不可能と㝘つても敢て過言ではない. 又一般ステリン類站びにサポゲニン類に 見られる栐に，溜融試驗に於ても融點降下を示さず，從て精製に一層の困難を生ずる，試みに Fp. $307^{\circ}$ (unkorr.) を示す Sojasapogenol-A と, Fp. 251 (unkorr.) を示す Sojasapogenol-B とを $1: 2$ の割合に混合して融點を测定すれば, $260^{\circ}$ 附近にて收縮し, $275^{\circ}$ 附近にて熔融する. 又 Sojasapogenol-B と Fp. $231^{\circ}$ (unkorr.) の Sojasapogenol-C とを 2:1 の割合に混合して Fp. を测定すれば， $240^{\circ}$ 附近にて收縮し，250附近にて熔融する.

又 Sojasapenol-A, -B, -C を 2:3:1 の割合に混合して熔融點を测定すれば, $250^{\circ}$ 附近にて 熔融する。然しその Acetat 例一ば Tetracetyl-sojasapagenol-A (Fp. 225 (unkorr.)) と Triacetylsojapogenol-B Fp. $175^{\circ}$ (unkorr.)) との混融試驗に於ては約 $20^{\circ}$ の融點降下を示す. 服部，荻村，奧村氏4).5) 等忙 Sojasaponin t Alkohol 硫酸で加水分解し，後水を加へて析出 する沈澱を遠心分離によつて捕集し，之を Alkohol から再結晶して, Fp. $249^{\circ}$ ，又は Fp. $241^{\circ}$ の Sapogenin を得て居る。著者は先づ Roh-Sojasaponin を Alkohol 硫酸によつて加水分解し。

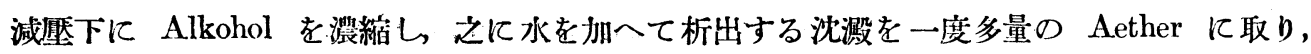
Aether 畨を $10 \% の$ Alkalilauge を䏳ひて充分洗涤し，酸性物質を完全に除去して，水洗乾燥 後 Aether を溜去し，殘渣を Methanol に溶解し，脫色炭を加へて精製し，次に之を Benzok 
溶液となし， $\mathrm{Al}_{2} \mathrm{O}_{3}$ 塔を通過させ，其の上層から Methanol を用ひて Fp. 290-295 附近を 示す物質を取り出し，更に之を Benzol 溶液となし $\mathrm{Al}_{2} \mathrm{O}_{3}$ 塔中を通過させ，その上層を分離す るか, 又は Methanol, Aceton を用ひて反覆再結晶を繰返し, $300^{\circ}$ 附近で收縮し, $305^{\circ} て ゙$ 熔融 し始め，307 (unkorr.) で完全に澄明に熔融する部分を集めて Sojasapogenol-A とし，又其の 中層からは同栐な方法により $247-8^{\circ}$ で收縮し，249で熔融し始め $251^{\circ}$ (unkorr.) で完全 に澄明に熔融する部分を集めて Sojasapogenol-B としたのである。著者の精製法を服部, 荻村, 奥村氏等のそれに比較して，其の Genin の諸性質を見れば，著者の得をる Sapogenol は服部， 荻村, 奧村氏等の得をる中性 Sapogenin よりも稍飞純粹かと考入られる。

本研究に於て終始愁切な御指導を賜つた 恩師朝比奈先生站びに桑田智博士に厚く感謝し，佾 材料を御送附願つた滿鐵中央試驗所の石四義豊博士，結晶學的檢查を施行せられた渡邊厚學士， 分析を施行せられた笠原，今井兩氏に厚く感謝する。

\section{實、驗 之 部}

\section{Sojasapogenin-I, -II, -III, -IV 等の分離}

滿洲座大豆のアルコールェキスを Benzol で極力脫脂し，乾燥した褐色粉未狀の粗製 Saponin $300 \mathrm{~g}$ を $5 \%$ の $80 \%$ Alkohol 性硫酸又は監酸 6 立と共に水浴上 40,30, 25 時間等種々の時間にて煮沸し, Alkohol を漕縮し，水を加へて Aether に振取する，之を $10 \%$ の Natronlauge で數回洗滌し，酸性物質を完全に 除去した後, Aether 層を水洗乾燥し, Aether を溜去すれば, 既に微黄色結晶性物質が析出する。 之を Me-

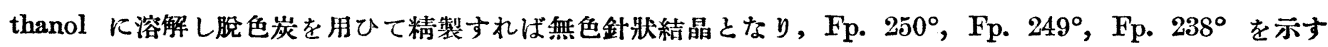
Sojasapogenin-I, -II, -III，が得られる，佾 Sojasapogenin-III を 15\%の Alkohol 硫酸中 20 時間煮沸 し，同粎にして Fp. 255。 を示す Sojasapogenin-IV を得た。得量は Roh-Sojasaponin に對して約 10\% である. Methanol, Alkohol, Chloroform 等に稍々難溶. Aether に易溶である. Sojasapogenin-I, -II, -III, -IV 等は其自身既に單一結晶形を有して居る様に見える。

\section{Sojasapogenin-I, -II, -III, -IV 等より Sojasapogenol-A, -B, -C の分離}

Sojasapogenin-I, -II, -III, -IV 等を精製 Benzol の約 $0.1 \%$ 溶液をなし, Merk 製の $\mathrm{Al}_{2} \mathrm{O}_{3}$ を充埧した 确子回筒中を通過させ, 其の上啳, 中首, 下層を各々 Methanol を用ひて浸出し, 佾 Methanol を用ひて

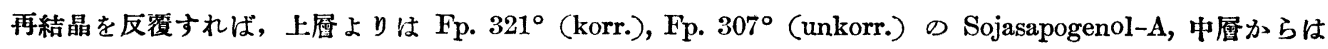
Fp. $260^{\circ}$ (korr.), 251 (unkorr.) の Sojasapogenol-B, 下層加らは Fp. $239^{\circ}$ (korr.), Fp. 231 ${ }^{\circ}$ (unkorr.) の Sojasapogenol-C が分離される。諸性質は粕論の部に述べた通り.

\section{Sojasap genol-A.}

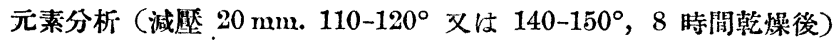

1) Sub. $\mathrm{mg} 3.425$

2) $\quad 3.845$

$\mathrm{CO}_{2} \mathrm{mg} \quad 9.470$

10.670

$\mathrm{H}_{2} \mathrm{O} \mathrm{mg}$

3.230

$\mathrm{C} \% \quad 75.41$

3.593

75.68

$\mathrm{H} \% \quad 10.55$

3) $\quad 4.445$

12.310

4)

3.225

8.955

4.215

75.53

10.46

5)

4.335

12.015

3.095

75.73

10.61

4.060

75.59

10.69

10.48

75.59

10.53 
分子量測定 (Rast 法), Sub. $0.0131 \mathrm{~g}$, Kampher $0.1667 \mathrm{~g}, \angle \mathrm{T}=7^{\circ}$, 分子量 450 .

\begin{tabular}{|c|c|c|c|c|c|c|c|}
\hline 分子式 & $\mathrm{C}_{28} \mathrm{H}_{48} \mathrm{O}_{4}$ & $\mathrm{C} \%$ & 74.96 & $\mathrm{H} \%$ & 10.75 & M.G. & 448.38 \\
\hline & $\mathrm{C}_{28} \mathrm{H}_{50} \mathrm{O}_{4}$ & & 74.60 & & 11.19 & & 450.40 \\
\hline & $\mathrm{C}_{29} \mathrm{H}_{48} \mathrm{O}_{4}$ & & 75.59 & & 10.51 & & 460.38 \\
\hline & $\mathrm{C}_{30} \mathrm{H}_{50} \mathrm{O}_{4}$ & & 75.89 & & 10.63 & & 474.40 \\
\hline & $\mathrm{C}_{299} \mathrm{HI}_{50} \mathrm{O}_{4}$ & & 75.26 & & 10.90 & & 462.40 \\
\hline
\end{tabular}

旋光度測定. $0.0438 \mathrm{~g}$ を Alkohol $10 \mathrm{cc}$ と溶解し $\mathrm{l}=2 \mathrm{dm}$ で觀測. $[\alpha]_{\mathrm{D}}^{9 ?}=+105.7^{\circ}$

二重結合數測定 (Hanus 法) 物質 $0.0678 \mathrm{~g}$ を Chloroform $20 \mathrm{cc}$ に溶解し, Bromjod 溶液 $10 \mathrm{cc}$

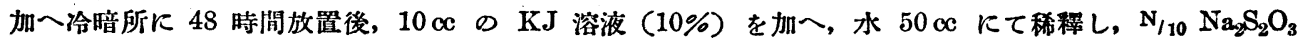
$(\mathrm{F}=0.997)$ にて滴定する。. Blindversuch にては N/10 $\mathrm{Nay}_{2} \mathrm{~S}_{2} \mathrm{O}_{3}$ 溶液 $31.7 \mathrm{cc}$ を消費し，梌踣を用ひた時 は $24.7 \mathrm{cc}$ を要す. 依て Jodzal $=130.5$ となる. 今 $\mathrm{C}_{29} \mathrm{H}_{48} \mathrm{O}_{4}$ とし $F_{1}$ とすれば Jodzal=55.14 故に F= 2.3 となる。

\section{Tetracetyl-Sojasapogenol-A.}

Sojasapogenol-A $0.4 \mathrm{~g}$ に無水醋酸 $10 \mathrm{cc}$, 無水醋酸曹達 $0.4 \mathrm{~g}$ を加へてハララフィン浴中 $160^{\circ}$ 附近に 3 時 間加熱後, 水を加一て無水醋酸を分解し, Aether に振取し, Alkali，水にて逐次洗滌後乾燥し, Aether を 溜去すれば結晶性殘淩を生ずる，之を Methanol より反覆再結晶すれば Fp. 2250 (unkorr.), Fp. 232 (korr.) を示す針狀無色の結晶を得る。

元素分析 (減壓 $20 \mathrm{~mm}, 150^{\circ}, 8$ 時間乾燥後)

\begin{tabular}{|c|c|c|c|c|c|c|c|c|c|}
\hline Sub. mg & 3.505 & $\mathrm{CO}_{2} \mathrm{mg}$ & 9.080 & $\mathrm{H}_{2} \mathrm{O} \mathrm{mg}$ & 2.740 & $\mathrm{C} \%$ & 70.65 & $\mathrm{H} \%$ & 8.75 \\
\hline & 3.275 & & 8.480 & & 2.545 & & 70.62 & & 8.69 \\
\hline ، & & & & 平 均 & & & 70.64 & & 8.72 \\
\hline $\mathrm{C}_{29} \mathrm{H}_{44} \mathrm{C}$ & $\mathrm{COCH}$ & $\llcorner し \tau$ & & & & & 70.65 & & 8.98 \\
\hline
\end{tabular}

分子量測定 (Rast 法). Sub. 0.0100 g. Kampher $0.1145 \mathrm{~g} . \quad \angle \mathrm{T}=5.5^{\circ}$. 分子量 635.1 .

$$
\mathrm{C}_{29} \mathrm{H}_{44}\left(\mathrm{O} \cdot \mathrm{COCH}_{3}\right)_{4} \text { として分子量 } \quad 628.5 \text {. }
$$

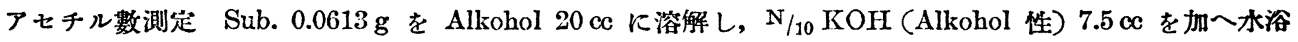
上 2 時間煮沸後 $\mathrm{N} / 10 \mathrm{HCl}(\mathrm{F}=1.001)$ にて還湘するに, $3.98 \mathrm{cc}$ を妰す. 別に宣檢により N/10 HCl $7.75 \propto c$ を要す. 依て $\mathrm{CH}_{3} \mathrm{CO} \%=26.45$ となる. Tetracetat $\mathrm{C}_{29} \mathrm{H}_{44}\left(\mathrm{O} \cdot \mathrm{COCH}_{3}\right)_{4}$ として $\mathrm{CH}_{3} \mathrm{CO} \%=27.37$. 滴定後之に水を加へて Aether に振取し, Aether を溜去すれば Sojasapogenol-A を间收する.

旋光度測定 Sub. $0.1068 \mathrm{~g}$ を Chloroform $10 \mathrm{cc}$ に溶解, $\mathrm{l}=1 \mathrm{dm}$ にて觀测. $[\alpha]_{\mathrm{D}}^{\prime \tau}=+86.1^{\circ}$

\section{Tribenzoyl-Sojasapogenol-A.}

Sojasapogenol-A $0.2 \mathrm{~g}$ を Pyridin $10 \mathrm{cc}$ に溶解し, 隶冷下に Benzoylchlorid $2 \mathrm{~g}$ を加一一畵夜放置後, 稀硫酸中に傾鴧し, 析出する沈涮を Aether に取り, Alkali, 水にて逐次洗滌し, Aether を乾㷘後溜去し, 結晶性殘㟆を Aceton, Methanol の同容混液より再結晶を反覆すれば, Fp. $255^{\circ}$ (korr.), Fp. 247 (unkorr.) に固定する無色鱗片狀の結晶を得る。

元素分析 (20 mm 減壓, $120-130^{\circ}, 5$ 時閒乾燥後)

\begin{tabular}{|c|c|c|c|c|c|c|c|c|c|}
\hline \multirow[t]{3}{*}{ 物質量 mg } & 3.605 & $\mathrm{CO}_{2} \mathrm{mg}$ & 10.240 & $\mathrm{H}_{2} \mathrm{O} \mathrm{mg}$ & 2.410 & $\mathrm{C} \%$ & 77.47 & $\mathrm{H} \%$ & 7.48 \\
\hline & 3.650 & & 10.360 & & 2.480 & & 77.41 & & 7.60 \\
\hline & 3.625 & & 10.260 & & 2.510 & & 77.19 & & \\
\hline & & & & 均 & & & 77.36 & & \\
\hline
\end{tabular}


分子量湘定 (ミクロ Rast) Sub. $0.204 \mathrm{mg}$,

$$
\begin{aligned}
& \mathrm{C}_{29} \mathrm{H}_{45} \mathrm{O}\left(\mathrm{O} \cdot \mathrm{C}_{6} \mathrm{H}_{6} \mathrm{CO}\right)_{3} \text { として } \\
& \mathrm{C}_{29} \mathrm{H}_{44}\left(\mathrm{O} \cdot \mathrm{C}_{6} \mathrm{H}_{5} \mathrm{CO}\right)_{4} \text { として }
\end{aligned}
$$

\begin{tabular}{|c|c|c|c|}
\hline ? & & $\Delta \mathrm{T}=6^{\circ}$ & M.G. $=765.8$. \\
\hline C\% 77.67, & $\mathrm{H} \%$ & 7.83 & $M . G=772.5$. \\
\hline 78.04, & 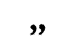 & 7.36, & " \\
\hline
\end{tabular}

\begin{tabular}{|c|c|c|c|c|c|c|c|c|c|c|c|}
\hline \multicolumn{12}{|c|}{ 元素分析 (減壓 $20 \mathrm{~mm}, 140^{\circ}, 8$ 時間乾燥) } \\
\hline \multirow[t]{2}{*}{ 物質量 } & mg & 3.425 & $\mathrm{CO}_{2}$ & $\mathrm{mg}$ & 9.82 & $\mathrm{H}_{2} \mathrm{O} \mathrm{mg}$ & 3.350 & $\mathrm{C} \%$ & 78.19 & $\mathrm{H} \%$ & 10.94 \\
\hline & & 3.675 & & & 10.53 & & 3.620 & & 78.18 & & 11.02 \\
\hline & & & & & & 本 均 & & & 78.19 & & 10.65 \\
\hline \multirow{5}{*}{$\begin{array}{c}\text { 分子量測足 } \\
\text { 分子式 }\end{array}$} & E $(R$ & Rast 法) & Sub. & & $113 \mathrm{~g}$ & Kampher & $0.1115 \mathrm{~g}$ & & $\mathrm{~T}=9.6^{\circ}$, & M.C & $=422.3$. \\
\hline & $\mathrm{C}_{27} \mathrm{~F}$ & $\mathrm{H}_{44} \mathrm{O}_{3}$ & & & $\mathrm{C} \% \mathrm{~T}$ & & $\mathrm{H} \%$ & 10.65 & & M.G & 416.4 \\
\hline & $\mathrm{C}_{27} \mathrm{H}$ & $\mathrm{H}_{4: 2} \mathrm{O}_{3}$ & & & & .19 & & 10.22 & & & 414.34 \\
\hline & $\mathrm{C}_{26} \mathrm{H}$ & $\mathrm{H}_{44} \mathrm{O}_{3}$ & & & & .16 & & 10.97 & & & 404.35 \\
\hline & $\mathrm{C}_{26} \mathrm{H}$ & $\mathrm{H}_{42} \mathrm{O}_{3}$ & & & & .36 & & 10.45 & & & 402.33 \\
\hline
\end{tabular}

6. Sojasapogenol-B.

旋光度測定 Sub. $0.1293 \mathrm{~g}$ を Alkohol $10 \mathrm{cc}$ K溶解し, $1=1 \mathrm{dm}$ Kて觀測, $[\alpha]_{\mathrm{b}}^{15}=+91.23^{\circ}$

二重結合數測定 (Hanus 法) Sub. $0.0648 \mathrm{~g}$ をChloroform $10 \mathrm{cc}$ と溶解し, Bromjod 溶液 $10 \mathrm{cc}$ を加 一, 48 時間放置後, $10 \% \mathrm{KJ}$ 溶液 $10 \mathrm{cc}$ を加人, 水 $50 \mathrm{cc}$ で稀释し, $\mathrm{N} / 10 \mathrm{Na}_{2} \mathrm{~S}_{2} \mathrm{O}_{3}(\mathrm{~F}=0.9901)$ で息 测するに $21.48 \mathrm{cc}$ を要す. 別に盲榆價 $31.74 \mathrm{cc}$ を得る。依て Jodzal=198.9. $F_{1}$ とし, $\mathrm{C}_{23} \mathrm{H}_{44} \mathrm{O}_{3}$ とす れば Jodzal $=60.95$. 依て $F=3.26$ を得る. Chloroform 層は常に褐色を呈し, $F=4.5, F=3.8$ 等の 值を得た事もある。

\section{Triacetyl-Sojasapogenol-B.}

Sojasapogenol-B $0.5 \mathrm{~g}$ と無水醋酸 $10 \mathrm{c}$, 無水醋酸曹達 $0.5 \mathrm{~g}$ を加へ, アスベスト上 2 時間热沸後, 水を 加一て無水醀酸を分解し, Aether に振取し, Alkalilauge, 水にて逐次洗滌後 Aether を溜去すれば, 結晶 析出する. 之を Methanol から反覆再結晶すると, 無色針狀の結晶となり, Fp. 180 (korr.), Fp. 175 (unkorr.) 凡固定する.

元素分析 (減壓 $20 \mathrm{~mm}, 140^{\circ}, 8$ 時間乾燥後)

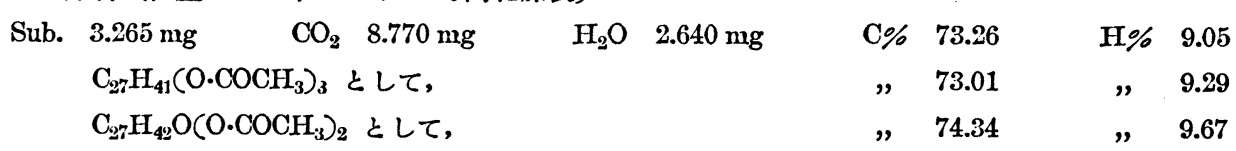

アセチ几數測定 Sub. $0.0512 \mathrm{~g}$ を Alkohol $10 \mathrm{cc}$ K溶解し, N/10 KOH (Alkohol 性) $10 \mathrm{cc}$ を加へ, 水 浴上に 2 時間惹沸した後, N/10 HCl $(\mathrm{F}=1.001)$ とて還測するに, $7.40 \mathrm{cc}$ を姴す. 別に盲检價 $10.05 \mathrm{cc}$ を得る. 依て $\mathrm{CH}_{3} \mathrm{CO} \%=22.26$. 今 Triacetat $\mathrm{C}_{27} \mathrm{H}_{41}\left(\mathrm{O} \cdot \mathrm{COCH}_{3}\right)_{3}$ として $\mathrm{CH}_{3} \mathrm{CO} \%=23.78$ となる. 滴定 後之に水を加へて Aether К振取し, Aether を溜去すれば Sojasapogenol-B 251 (unkorr.) を回收する.

$$
\begin{aligned}
& \text { 分子量測定 (ミクロ Rast) Sub. } 0.160 \mathrm{mg}, \quad \text { Kanpher } 1.777 \mathrm{mg}, \quad \angle \mathrm{T}=6.5,^{\circ} \quad \text { M.G. }=554.1 \\
& \mathrm{C}_{27} \mathrm{H}_{41}\left(\mathrm{O} \cdot \mathrm{COCH}_{3}\right)_{3} \text { として M.G. }=542.4
\end{aligned}
$$

旋光度測定 Sub. $0.1567 \mathrm{~g}$ を Chloroform $10 \mathrm{cc}$ K溶解し, $\mathrm{I}=1 \mathrm{dm} \kappa \tau$ 觀測. $[\alpha]_{\mathrm{D}}^{16}=+82.96^{\circ}$

\section{Tribenzoyl-Sojasapogenol-B.}

Sub. $0.2 \mathrm{~g}$ を Pyridin $10 \mathrm{cc}$ と溶解し, Benzoylchlorid 凡依り常法の如く Benzoat を作り, Aecton, Methanol の同容混液より反覆再結晶すれば, Fp. $183^{\circ}$ (korr.), Fp. $179^{\circ}$ (unkorr.) と固定する無色短針狀の 粘晶を得る。 


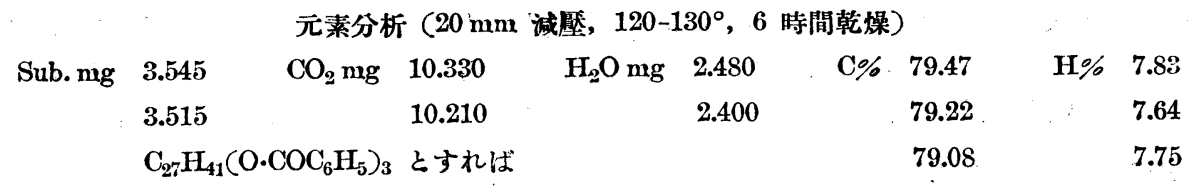

分于量測定 (ミクロ Rast) . Sub. $0.202 \mathrm{mg}$ ，Kampher $2.45 \mathrm{mg} \quad \Delta \mathrm{T}=4.6^{\circ}, \quad$ M.G. $=720.1$.

$$
\mathrm{C}_{2 i} \mathrm{H}_{41}\left(\mathrm{O} \cdot \mathrm{COC}_{6} \mathrm{H}_{5}\right)_{3} \text { とすれば～M.G. }=728.45 \text {. }
$$

\section{Sojasapogenol-C.}

元素分析 減壓 $20 \mathrm{~mm}, 140^{\circ}$ にて 7 時間乾燥後

Sub. $4.370 \mathrm{mg} \quad \mathrm{CO}_{2} \quad 12.800 \mathrm{ng} \quad \mathrm{H}_{2} \mathrm{O} \quad 4.190 \mathrm{mg} \quad \mathrm{C} \% \quad 79.88 \quad \mathrm{H} \% \quad 10.73$

分子量測定 (ミクロ Rast) . Sub. $0.210 \mathrm{mg}, \quad$ Kampher $2.302 \mathrm{mg}, \quad \Delta \mathrm{T}=11^{\circ}$., M.G. $=330.2$.

\begin{tabular}{|c|c|c|c|c|c|c|c|}
\hline 分子・式 & $\mathrm{C}_{23} \mathrm{H}_{36} \mathrm{O}_{2}$ & $\mathrm{C} \%$ & 80.16 & $\mathbf{H} \%$ & 10.54 & M.G. & 344.29 \\
\hline & $\mathrm{C}_{23} \mathrm{H}_{34} \mathrm{O}_{2}$ & & 80.64 & & 10.01 & & 342.27 \\
\hline & $\mathrm{C}_{22} \mathrm{H}_{36} \mathrm{O}_{2}$ & & 79.45 & & 10.92 & & 332.29 \\
\hline & $\mathrm{C}_{22} \mathrm{H}_{34} \mathrm{O}_{2}$ & & 79.93 & & 10.37 & & 330.27 \\
\hline
\end{tabular}

1) 農化 5. 737 (1929). 2) A. 489. 118 (1931). 3) 苌化 9. 1249 (1933).

4) 衞化 5. 313 (1933). 5) 衞化 8. 19 (1936). 6) J. Biolog. Chem. 108. 55 (1935). 